\title{
ENTRE A PLUTOCRACIA E A LEGITIMAÇÃO DA DOMINAÇÃO FINANCEIRA*
}

\section{Roberto Grün}

\section{Introdução}

O predomínio da esfera financeira na sociedade brasileira gera uma dinâmica cultural engendrada no atrito entre aqueles que a apóiam e os que a rejeitam sistematicamente. $O$ ponto de partida deste artigo é discutir a formação do "plutocrata”, figura típica que expressa aquela tensão. Se

* Agradeço ao CNPq e à Fapesp pelos auxílios à pesquisa nos quais levantei os dados e realizei as análises que resultaram no presente artigo. Agradeço também aos colegas do Nesefi/UFSCar e da rede de pesquisas reunida em torno do CRBC/EHESS, bem como aos pareceristas anônimos da RBCS pelas críticas e comentários que me ajudaram a dar a forma final ao texto.

Artigo recebido em agosto/2006

Aprovado em dezembro/2006 a dominação financeira é um fenômeno mais amplo do que o simples controle econômico da sociedade, a exploração da dinâmica e da polissemia na qual o "plutocrata" nasce e se desenvolve pode ser uma boa entrada para a análise sociológica. Evidentemente, esse caminho não pre- tende esgotar a compreensão científica de tal configuração, mas apenas chamar a atenção para uma das facetas desse fenômeno até agora pouco explorado. ${ }^{1} \mathrm{O}$ principal material empírico colhido para a análise vem da CPI dos Correios de 2005-2006. Ela se constituiu uma janela excepcional, na qual se expuseram personagens pouco propensos a aparições públicas, em especial o banqueiro Daniel Dantas, em torno do qual se construiu uma imagem que lembra a figura do "plutocrata".

O mundo gira e os símbolos vão e voltam no tempo e no espaço. O Brasil contemporâneo criou uma série de figuras públicas semelhantes ao "plutocrata". Pode-se dizer que esse tipo se configurou na segunda metade do século XIX na 
Europa e nos Estados Unidos, e desde os anos de 1930 passou a freqüentar nosso imaginário , a partir do trabalho ideológico da extrema direita. Entre as personalidades que compõem tal categoria, podemos citar Horácio Lafer, personagem principal da sinagoga paulista de Barroso (Maio, 1992); antes dele, durante a crise do encilhamento, o próprio Ruy Barbosa, candidato a essa "honra" (Diniz, 1996). Recentemente, segundo a exposição pública observada na mídia, pudemos observar uma galeria de indivíduos para os quais setores da sociedade tentam atribuir esse papel em diversas variantes: Naji Nahas, Benjamin Steinbruch, Armínio Fraga e Daniel Dantas.

Os plutocratas aparecem na esfera pública em episódios que de alguma forma chocam a sensibilidade social a respeito do funcionamento da economia ou da política. Mormente em escândalos, ainda que para que um indivíduo assuma esse papel ele tenha de ser "preparado" antes, para que, uma vez deflagrado o evento, as atenções se dirijam ao indigitado. Por outro lado, podemos olhar os escândalos como parte obrigatória da história das finanças, na medida em que eles fazem a sociedade, em especial seus sistemas de representação política e de regulação econômica, romperem a inércia de cooperação quase automática com agentes econômicos específicos, que pode ser prejudicial ao sistema econômico como um todo.

Um caso recente, e de extrema relevância, é a lei Sarbanes-Oxley, o aperfeiçoamento das leis de governança corporativa que foram rapidamente concebidas e votadas nos Estados Unidos, na esteira do escândalo da Enron (Blair, 2003a e b) e cuja promulgação provocou transformações nos mercados financeiros do mundo inteiro (Gates, 2003). As diversas inovações introduzidas naquela rodada já estavam disponíveis no arcabouço de soluções jurídicas norte-americano, mas, segundo fontes jornalísticas, as várias relações "promíscuas" que setores do Legislativo e do Executivo daquele país entretinham com agentes e interesses particulares do mundo financeiro acabavam impedindo que elas fossem promulgadas (David E. Sanger e Richard A. Oppel, 2002; Labaton, 2002; Coffee, 2002). Podemos, assim, inferir o paradoxo de que os escândalos são parte integrante da regulação do capitalismo contemporâ- neo (De Blic, 2005). Dessa forma, seu estudo reveste-se de uma importância muito maior do que a simples exploração de momentos idiossincráticos da história (Mackenzie, 2006).

A formação da imagem dos plutocratas varia, evidentemente, com os arcabouços culturais disponíveis e mobilizáveis pela mídia e pelo campo político em determinados lugares e momentos. Nos casos anteriores, o termo "plutocrata", então em sintonia com a imprensa e as pregações internacionais, era usado também no Brasil. Depois da derrota dos fascismos europeus, ele entrou para a galeria dos arcaísmos. Mas o conteúdo parece se manter, ao menos em parte. O poder do dinheiro, conseguido por arrivistas sem vínculo com o mundo da produção, é usado contra os interesses populares e da nação. Um indivíduo ou um pequeno grupo de financistas manipula os espaços econômicos e corrompe os políticos segundo seus interesses, graças ao poder do dinheiro e da sua desfaçatez. O resultado de situações e processos que não seguem de acordo com os desfechos esperados pelos que os denunciam é imputado aos plutocratas, que passam, assim, a encarnar os males da época. O plutocrata tradicional da Europa costuma ser judeu, oriundo do mundo das finanças, e sua evocação faz parte normalmente do repertório retórico da extrema direita fascista ou próxima (Birnbaum, 1979). Nos Estados Unidos, ele pode ser confundido com os robber barons, como os Rockfellers ou Andrew Carnegie, que monopolizaram setores industriais considerados vitais para a economia dos Estados Unidos. Não eram judeus, ainda que fossem representados graficamente como tais, brandidos principalmente pelo movimento populista (McGerr, 1986, 2005).

O ponto que singulariza a situação brasileira do final do século XX e início do XXI, tanto em relação ao nosso passado como à cena internacional, é a seqüência de "candidatos" ao posto de plutocrata e a aparente estabilização desse personagem na construção elaborada a partir da figura de Daniel Dantas. ${ }^{2}$ As hipóteses que se depreendem dessa configuração são: 1) que a procura de um plutocrata denota um mal-estar da sociedade brasileira em relação ao sistema financeiro; 2) que a figura de Daniel Dantas se reveste de características necessárias para pensar e transmitir esse 
incômodo; 3) que tais necessidades simbólicas denotam, simultaneamente, a gestação e a oposição a uma configuração simbólica e econômica que podemos chamar de "modo de dominação financeiro".

\section{O mar das ambigüidades e a galeria dos personagens}

À primeira vista, os termos "mal-estar" e "incômodo" parecem excessivamente frouxos para servirem de base a uma hipótese científica. Entretanto, tal frouxidão, a ambigüidade de sentidos, é parte essencial tanto da configuração cultural que dá base às disputas econômicas que ocorrem na sociedade brasileira atual, como condição para a eficácia social dos "totens" erigidos para simbolizá-las (Darnton, 1986; Bourdieu, 1997).

Na seqüência que proponho, Naji Nahas aparece inicialmente como um "mega-especulador", cujas manobras ousadas e heterodoxas teriam manchado a reputação da Bovespa e, assim, comprometido o desenvolvimento do mercado de ações brasileiro. Por causa disso, ele foi formalmente banido desse espaço e continua "purgando seus pecados" (Attuch, 2004). A partir de então, aparecem alguns elementos iniciais da trama: a) o espaço das finanças não goza de legitimidade automática na sociedade brasileira, precisando controlar seus membros a ponto de ter de sacrificar um indivíduo importante; b) subsidiariamente, temos que a trama específica que provocou a sua evicção opôs Nahas, um "libanês naturalizado brasileiro", ao então presidente da Bovespa, Eduardo da Rocha Azevedo, que ostenta um sobrenome brasileiro tradicional - índice importante de respeitabilidade que, conforme veremos adiante, tem valor nesse espaço ("Ministro Rocha Azevedo é o nome de uma rua importante da cidade de São Paulo, situada nos "Jardins"). De qualquer maneira, diante do perigo representado pelo indivíduo que a linguagem corrente chama de "turco", o mercado recompõe a sua imagem institucional, evitando que ele adquira perenemente a imagem de "plutocrata", ainda que a imprensa e políticos tenham flertado com essa possibilidade.

Nossa galeria segue com a figura de Benjamin Steinbruch. Protagonista destacado do processo de privatização das companhias estatais empreendido nos governos FHC, esse personagem é de origem judaica, o que é uma característica importante para a qualificação de plutocrata, abrindo amplas possibilidades simbólicas para seus detratores. Afinal, o "tipo-ideal" de plutocrata na tradição européia é um judeu mais ou menos identificado à família Rothschild, quer dizer: de origem asquenaze, com braços da família atuando internacionalmente, de maneira a caracterizar implicitamente a falta de ligação com a pátria (Marrus, 1985; Pinçon, 1998; Schor, 1992). Mas, ainda que essa saliência tenha sido brandida esporadicamente, esse nosso personagem também não parece reunir as melhores condições para ganhar esse cetro duvidoso. A origem do seu grupo econômico é industrial e ele jamais deixou de se identificar nessa rubrica. Como veremos, tal característica também pesa na trama.

Armínio Fraga, presidente do Banco Central durante o segundo mandato de FHC, pode ser considerado o candidato seguinte à função de plutocrata. ${ }^{3}$ Nesse caso, a principal associação foi sua condição anterior de gerente de fundos de investimentos pertencentes ao "plutocrata internacional" (e judeu) Georges Soros. Nesse enquadramento, tentou-se inserir a figura de Fraga na esteira da imagem de seu associado. Esforços persistentes nesse sentido foram realizados por diversos atores situados na esquerda do espectro político, pretendendo, assim, demonstrar a submissão do governo federal da época ao braço mais agressivo, e já estigmatizado, das finanças internacionais (Guilhot, 2004). Mas, mais uma vez, a imagem não se manteve. A figura de Fraga aparecia freqüentemente oposta à de Gustavo Franco, anterior presidente da mesma instituição, tido como muito mais ortodoxo do que ele e responsável pela crise cambial do final de 1998. Além disso, ele foi incensado por parte da imprensa como um modelo de refinamento "despojado", e a sua figura pública não se associou diretamente ao processo de privatização.

Voltemos, então, a Daniel Dantas, que completa (provisoriamente) nossa galeria. Sua figura parece ser a mais adequada para ocupar o papel do plutocrata. Ele foi protagonista ativo do processo de privatização, é banqueiro conhecido pela agressividade de sua estratégia e pelo cresci- 
mento vertiginoso do banco, bem como o sucesso público de suas empreitadas de maneira geral, que coincidem com a privatização das empresas públicas e a "financeirização" de muitos ambientes de trabalho. Além disso, a postura econômica que esse ator encarna é facilmente vista como um microcosmo da violência que as finanças exercem sobre as sociedades mediante a arbitragem monitoramento e ataque impiedoso dos mercados financeiros internacionais contra os países que ousam adotar políticas econômicas que não estejam de acordo com os "fundamentos sadios" propalados pelo senso comum produzido naquele espaço (Guex, 2003; Grün, 2004a).

\section{Os bons símbolos e o símbolo ótimo}

Um primeiro ponto a ser destacado dessa seqüência de nomes é a sua própria constituição. A meu ver, ela indica que a sociedade brasileira precisa e procura incessantemente um símbolo bom para pensar a predominância das considerações financeiras sobre outros arrazoados, o que parece ser flagrante nos últimos anos. Assim, a dinâmica cultural faz com que diversos indivíduos virem suportes materiais para a construção desse totem moderm. Mas, não servindo integralmente para representar e discutir a ordem financeira, eles desaparecem e/ou são substituídos por outros mais adequados. É assim que Dantas, cujo processo de simbolização já estava em gestação na década de 1990 , parece estabilizar-se no papel social do "plutocrata", esmaecendo a imagem dos outros "candidatos".

O histórico de sua notoriedade pode ser facilmente aferido na pesquisa das menções ao seu nome nos jornais e revistas desde a década de 1990. Mais recentemente, diversos episódios em torno da crise do "mensalão", ocorrida em meados de 2006, dão cor à sua imagem. O novo banqueiro foi pintado como um demiurgo, uma espécie de diretor do teatro de marionetes, no qual os políticos e demais participantes do problema seriam meros títeres, por ele manipulados (Leite, 2005). Como revelam as manchetes de diversos periódicos, estariam a seu serviço desde as bancadas do PT, passando por peemedebistas e outros menos votados, até as do PFL: "O orelhudo tá nessa: as conexões entre Daniel Dantas, Marcos Valério, integrantes do PT e o depoimen- to da secretária" (Lírio, 2005), "O Sinhozinho: Heráclito Fortes agride repórter do Piauí que quis saber sobre seu apoio a Dantas" (Carta Capital, 2005), "Deputado do PFL 'clona' ação a favor do Opportunity" (Souza e Alencar, 2005) e "Briga empresarial ajudou a pôr Dirceu e Gushiken em campos opostos" (Helena Chagas, 2005).

Vemos, assim, a imagem do nosso plutocrata se robustecendo pro g ressivamente. Sua consolidação recente, associada ao papel que lhe imputam no escândalo do "mensalão", inicia-se em rumore s e sites próximos ao grupo dirigente responsável pelas dificuldades que a crise provocou no PT. A pa rece na revista Carta Capital, publicação nitidamente fora do centro do jornalismo nacional (Lírio, 2005) e caminha daí para o centro, re presentado pelos jornais O Globo (Peña, 2005), Valor Econômico (Romero, 2005) e Folha de São Paulo (Souza e Alencar, 2005). O trajeto da versão na mídia indica nele mesmo a formação de um consenso de que a explicação em torno de Dantas merece alguma credibilidade entre os fazedores de opinião. Afinal, em caso contrário a mídia não p roduziria essa pauta, não veicularia a versão de sua culpabilidade nem de sua inocência. ${ }^{4}$

Podemos pensar o encadeamento da formação da imagem do plutocrata em dois planos de análise distintos. O primeiro é interno à questão simbólica. É evidente que as descrições de nossos personagens nos fazem prestar atenção ao subconjunto das características que confirmam a imagem de plutocrata, lembrando que tal imagem já faz parte do repertório político das sociedades ocidentais e, assim, ela acaba se tornando uma espécie de taked for granted. As associações e as seqüências mnemônicas têm uma aparência natural e familiar que contribuem para criar verossimilhança. Por isso, dificilmente elas seriam questionadas (Ginzburg, 1992). Estamos, portanto, diante de um arquétipo que viaja no tempo e no espaço, ainda que destituído de seu nome próprio consagrado na historiografia. ${ }^{5}$ A estrutura simbólica que suporta essa migração cultural não é perfeitamente clara, mas nem por isso a evidência deve ser descartada. Salta aos olhos o fato de o "mensalão" ser um artefato cultural próximo ao chéquard do escândalo do canal do Panamá do final do século XIX e que a imagem pública de "Marcos Valério" lembra o personagem Stavisky 
da França que precedeu o Front Popular (Agulhon, 1990). Assim, a migração de conteúdos (ou estruturas) culturais pode e deve ser objeto de uma minuciosa pesquisa histórica que demonstre o trajeto percorrido e os suportes físicos e simbólicos que conduzem a sua difusão (Ginzburg, 1989). Mas, embora essa empreitada seja, evidentemente, importante e instigante, não me ocuparei dela no momento.

O outro plano diz respeito de qual realidade se trata e as razões situadas da estabilização do nosso suporte simbólico. Parafraseando LéviStrauss, a pergunta é refeita: Quais características singularizam Daniel Dantas diante dos outros candidatos para, a partir dele, a sociedade brasileira construir um totem "melhor para pensar" a sua relação com o mundo das finanças?

A resposta permite também delinear o processo de legitimação do nosso modo de dominação financeiro. Os eventos ocorridos em torno do depoimento de Daniel Dantas na CPI concentraram a atenção do sistema político e da mídia sobre o personagem, o que nos ajuda a responder a questão. ${ }^{6}$ Em primeiro lugar, o parlamento dividiu-se entre aqueles que o atacavam e os que o defendiam, todos com ardor e belicosidade, o que já de saída denota a importância do caso (Peña, 2005). Para seus apoiadores, nele se concentrava todas as características que um empreendedor moderno deveria possuir. Muito além das prosaicas justificativas de "proteção aos nossos financiadores" ou "portador de segredos que poderiam embaraçar os partidos responsáveis pelo governo FHC", Dantas apareceu na CPI como um herói a ser preservado a qualquer custo da sanha acusatória dos passadistas "estato-latras" e corporativos ligados ao PT. Para os petistas mainstreamers, ligados aos sindicatos, ele aparecia como o grande inimigo no espaço financeiro. À medida que os sindicatos passaram a disputar o controle dos fundos de pensão, eles encontraram uma justificativa para essa atuação, arvorando-se em defensores dos interesses dos trabalhadores e do desenvolvimento econômico sadio no seio do mercado financeiro - os "domadores do capital financeiro" (Jardim, 2005). Esse grupo tem apresentado um discurso que parece abraçar a velha tese do commerce doux do século XVII, recuperada por Hirschman (1992). Nesse contexto, Dan- tas representa a encarnação mesma da fera a ser enfrentada. Para os petistas não comprometidos com o mercado financeiro (provavelmente aqueles oriundos dos movimentos sociais de origem religiosa), ou para os atores políticos que abandonaram recentemente o partido, Dantas representa tal mercado em geral. Ele é temido e rejeitado in totum (Cariello, 2006). Nas palavras da senadora Heloísa Helena (PSOL-AL):

\begin{abstract}
Durante toda a minha militância no PT, eu sempre ouvi falar sobre V. $S^{a}$. Era meio como o Lúcifer, o gênio do mal, alguém preparado para todas as piores coisas, ardilosas, para tudo aquilo que, na minha opinião, é da essência do capitalismo: a chantagem, o suborno, a espionagem, a corrupção. Só que a imagem que eu tinha de V. $S^{a}$ é a mesma que eu sempre tive - e tenho - do Sr. Henrique Meirelles também. Então, o que para mim é a expressão da excrescência do capitalismo é a mesma coisa: o Sr. Henrique Meirelles, indicado pelo Presidente Lula como Presidente do Banco Central... Para mim, é tudo a mesma coisa (Senado, 2005b, disponível no site http:// www.senado.gov.br/sf/atividade/Comissoes).
\end{abstract}

\section{Um totem polissêmico}

Como vemos, produzindo pelo menos três imagens, Daniel Dantas tornou-se um símbolo ainda mais amplo do que Janus, o deus das duas faces. Essas ambigüidades seriam problemáticas para a construção social do símbolo da dominação financeira sobre a sociedade brasileira? A resposta seria afirmativa somente se essa nova ordem atraísse ou a adesão ou a repulsa geral, o que é praticamente impossível numa sociedade complexa. Como se trata de uma evolução controvertida da sociedade, as ambigüidades acabam se tomando uma solução para o problema da sua representação (Hacking, 1983; Ginzburg, 1991; Bourdieu, 1997; Goody, 1997). Dantas é, evidentemente, um totem polissêmico, que pode ser utilizado por diversos atores e estratégias retóricas, estruturando raciocínios econômicos e políticos diferentes, e mesmo antagônicos. É assim que, ao contrário de seus predecessores, sua imagem apareceu, cresceu e se mantém na cena midiática dos últimos anos. Para o bem ou para o mal, seu protagonismo é sempre reconhecido. E se alguém ainda pudesse 
duvidar da importância desse personagem, bastaria lembrar que sua ausência no relatório da CPI provocou a formação de uma frente suprapartidária para incluí-lo (Marques, 2006).

Tal sucesso, comparado à pouca aderência dos outros "candidatos", pode servir de algoritmo para entendermos as peculiaridades da configuração, inextricavelmente simbólica e econômica, que ganha corpo no Brasil contemporâneo. Caminhando, assim, de trás para frente, podemos comparar Dantas e Nahas. Enquanto este é visto com desconfiança, como um outsider completo, e mesmo um arrivista sem ramificações na sociedade, operando apenas nos mercados financeiros e para sua própria fortuna, aquele é nomeado como descendente do Barão de Jeremoabo (Gaspari, 2006) e entra no circuito financeiro por intermédio de Mario Henrique Simonsen (Leite, 2005). Trata-se, assim, de um patrício com plenos direitos, digno de freqüentar as elites e de obter a boavontade governamental para suas empreitadas. Seu banco serve a grandes investidores, e a ação de deputados e senadores oriundos do grupo que sustentava FHC durante o depoimento de Daniel Dantas na CPI tira quaisquer dúvidas a respeito de seu entrosamento na ordem financeira definida durante os anos do governo FHC (Peña, 2005). Surge daí uma outra constatação importante: se a ordem financeira é um espaço do patriciado, quem não se encaixa nesse figurino, ou em alguma variante dele, tem de pagar um enorme preço para tentar legitimar-se, e o corolário é que qualquer erro nesse sentido faz o processo de legitimação retroceder. No espaço internacional, os novos financistas "metecos" pagam uma significativa taxa de adesão, bem como são compelidos a alimentar continuamente a sua imagem, trocando vultuosas doações filantrópicas por legitimidade social (Guilhot, 2004, 2006). No Brasil, observamos, entre outros exemplos, a família Safra invocando uma tradição secular de atividade bancária no Oriente Médio, na Europa e nos Estados Unidos, e Edemar Cid Ferreira, ex-dono do Banco de Santos, tornando-se um patrocinador de alta visibilidade no terreno das artes visuais. Assim, por caminhos diversos, os dois grupos ensaiam pavimentar seu caminho rumo ao patriciado (Carvalho, 2006a e b).

A "prova de contraste" seguinte opõe Dantas a Benjamin Steinbruch. Segundo a tradição européia, este ator de origem e nome indisfarçavelmente judaicos deveria ser um forte candidato ao posto de primeiro plutocrata no Brasil. Nesse sentido, a comparação servirá também para evidenciar algumas peculiaridades brasileiras sobre o fenômeno. Podemos constatar diversas tentativas de colar o rótulo neste personagem, como por exemplo um livro publicado por uma editora pertencente a jornalistas de alto perfil midiático e com prefácio de Paulo Pereira, o Paulinho da Força, que foi presidente, também de grande visibilidade, daquela importante central sindical (Tiezzi, 2006). Entretanto, ainda que não faltem empreendedores morais ensaiando criar tal associação, ela pode até ter uma forte repercussão local, mas não se difunde na sociedade. A origem industrial da saga econômica de Benjamin Steinbruch parece protegê-lo de qualquer associação infamante. Mas é interessante que sua trajetória prepondere sobre uma possível vinculação deste personagem ao mundo financeiro, mesmo que ele já tenha sido membro do Banco Fibra. ${ }^{7}$ Com efeito, o anti-semitismo não parece ter deitado raízes profundas na sociedade brasileira: mesmo numa conjuntura favorável para acionar aquele repertório, ele não funciona. ${ }^{8}$

Uma outra comparação recai sobre a figura de Armínio Fraga, que também foi objeto de intenso bombardeio moral, ao ser acusado de tentar ganhar proveito de sua relação com Soros, considerado o grande vilão para os inimigos atuais das finanças. Na época da ascensão de Fraga ao posto de presidente do Banco Central, Soros estava no centro de uma polêmica com o então Primeiro Ministro da Malásia, Mahathir Mohamad, que o acusava pela crise que seu país atravessara entre 1997 e 1998 (The Economist, 1997a e b). O grande especulador teria deflagrado uma corrida contra a moeda desse país, e as acusações chegaram até a flexionar o repertório do anti-semitismo, quando Mahathir Mohamad discursou na Conferência dos Países Islâmicos (Cohen, 2002). Havia, assim, um halo de verossimilhança para produzir a associação. Mas Fraga não serviu ao estereótipo. Isso porque, de um lado, grande parte da imprensa e dos analistas de mercado contrastaram sua "flexibilidade" à "ortodoxia" de Gustavo Franco, de outro, ele obteve uma cobertura mundana muito favorável, 
destacando a sua origem patrícia e seu refinamento ascético (Dias, 2000). Por fim, diversas notícias davam conta de tratativas para mantê-lo no cargo de presidente do Banco Central no início do governo Lula, denotando um reconhecimento ampliado de seu desprendimento patriótico (Gaspari, 2002; Época Online, 2002; Traumann, 2002).

Vale destacar também que o personagem A rmínio Fraga parece ter passado ao largo do processo de privatização, não se envolvendo assim, ao menos publicamente, com a questão mais controversa do período. Posteriormente, já no governo Lula, Fraga aparecerá como gestor independente de fundos de investimentos e uma espécie de herói das novas gerações do espaço financeiro, indicando não só as boas estratégias de negócios, como também um art de viure legítimo para os membros desses grupos. Já Daniel Dantas não parece ter realizado nenhum investimento de legitimação perante o grande público. Muito pelo contrário, ele é sido acusado de ter escolhido o caminho inverso no sentido de manter o controle das situações delicadas por que passam seus negócios mediante a espionagem de seus eventuais adversários, alimentando, assim, o estereótipo do plutocrata (Michael, 2004; Helena Chagas, 2005). E mais do que isso, ele foi, talvez, a figura, que vinha do setor privado, mais saliente do processo de privatização e também dos rearranjos societários que o seguiram.

É possível entender, assim, por que Daniel Dantas tornou-se "favorito" para assumir o papel social do plutocrata. De um lado, a confirmação dos atributos mais ou menos gerais que compõem tal papel: ele manipularia indivíduos, instituições e agendas para promover seus interesses particulares; disporia de recursos para isso e não hesitaria em usá-los, inclusive acaparando fundos das empresas que administra como delegado (Mendes, 2006). De outro lado, ao se tornar o grande "demiurgo" da privatização, ele interferiria diretamente numa esfera da vida econômica e social que deveria ser autônoma relativamente às finanças. Nesse caso, notemos que sua presença na configuração tem efeito social diferente daquele que poderíamos esperar em relação a Steinbruch ou Antônio E rmírio de Moraes, que, por terem vindo da ordem industrial, têm suas presenças legitimadas no processo de privatização.

\section{Mundo das finanças e mundo das artes}

A esfera política abre outros caminhos analíticos: vimos na CPI diversos atores atacarem Daniel Dantas de pontos de vista que claramente indicam o mundo financeiro visto pelo ângulo dos fundos de pensão; vimos também aqueles que, ao inquirir Dantas, lançavam um anátema a todo o sistema financeiro; e ainda aqueles que defendiam esse personagem, procurando resgatar sua "positividade". Temos, assim, dois contenciosos sobrepostos: um interno ao campo financeiro e outro opondo o espaço financeiro a representantes imputados de outros setores da sociedade. No primeiro, há um claro jogo interno ao campo do poder. Schumpeter, nos primórdios da sociologia das finanças, já havia observado que as estruturas sociais das finanças são a ossatura das estruturas mais gerais das elites sociais e que seus contenciosos revelam justamente as disputas no seio das elites (Schumpeter e Swedberg, 1991, p. 101). Durante os oito anos da presidência de FHC, os "novos" banqueiros, dos quais Dantas é o exemplo mais acabado, gozavam de uma enorme boa-vontade do governo federal e de suas agências reguladoras e de fomento, à custa dos dirigentes de fundos de pensão e dos agentes tradicionais do mercado financeiro. No governo Lula, a gangorra inclinou-se um pouco mais para esses dois últimos grupos. O desvelamento dos episódios de espionagem empresarial e de dirigentes governamentais que têm Dantas e Kroll como acusados são a face visível desse contencioso, que envolveu o comando e a propriedade de empresas privatizadas no governo anterior (Vieira, 2003; Folha Online, 2006). Num primeiro momento, tudo indicava que o governo Lula favoreceria a inversão total do jogo. Posteriormente, parece que se chegou a alguma acomodação (Romero, 2005). Afinal... vivemos no paraíso da conciliação das elites.

Mas este exemplo permite avançar a análise no sentido de constatar uma componente constante da estrutura social brasileira. Se olharmos a morfologia social da disputa, percebemos que Dantas exemplifica um grupo que poderíamos chamar de "vanguarda financeira". Há, de fato, uma homologia entre a posição das nossas recém- 
denominadas vanguardas financeiras no campo econômico e as vanguardas literárias e visuais no campo da arte: de um lado, na produção de inovações no espaço em que atuam e nas condições sociais que permitem tal ousadia; ${ }^{2}$ de outro, na libido que impulsiona tais práticas. No campo artístico, os interesses materiais têm de ser denegados para compor com as formas de legitimação do espaço (Bourdieu, 1992). Acontece o contrário no campo financeiro. Para serem legitimados, os interesses não econômicos têm de ser denegados e expressos pela retórica econômica da racionalidade. Uma vez que o campo financeiro é parte do campo do poder, a libido dominandi é a base da economia pulsional mais geral do espaço, ainda que apareça envolvida pela retórica da necessidade e do interesse econômicos (Rieder, 1990; Lordon, 2002).

A atuação de Dantas pode ser entendida como uma postura vanguardista no espaço econômico e financeiro: ele leva ao extremo a tendência à financeirização dos espaços econômicos e usa os instrumentos financeiros, em especial a "alavancagem", de maneira muito mais ampla do que o padrão até então aceito nesse espaço. ${ }^{10}$ Assim, como uma espécie de tipo-ideal de postura financeira, seu grupo utiliza mais capitais de terceiros do que o habitual; as empresas que ele administra utilizam também com maior intensidade e amplitude tanto a terceirização de trabalho e de atividades como os recursos das empresas que atua como representante para realizar as finalidades específicas do seu grupo. ${ }^{11}$ Seus antecessores ou não pensaram nas alternativas trilhadas por Dantas, ou consideraram-nas excessivas. Mas uma vez postas em uso, elas passam a fazer parte do arsenal de "ferramentas" aceitas, ao menos parcialmente, pelo mercado. Afinal, a concorrência obriga os demais agentes a levar em conta a performance das vanguardas, inclusive porque os clientes passam a exigir níveis de rentabilidade equivalentes. Dessa maneira, ou ele revoluciona o espaço em que atua, obrigando outros atores a alterar suas práticas ou aceitarem a perda de espaço, ou seus adversários conseguem impugnar suas ousadias.

As transformações do espaço financeiro e econômico no Brasil seguem em grande parte um padrão internacional. Num primeiro plano, as inovações surgem de uma dinâmica social impulsio- nada por um contencioso geracional. Thompson (1997a e b) mostra esse padrão fazendo valer a sua força nas transformações da City londrina londrinas depois do Big Bang financeiro dos anos de 1980. Mackenzie (2006), por sua vez, mostra como o desenvolvimento recente do mercado de opções nos Estados Unidos foi o resultado da ação de verdadeiros empreendedores morais, movidos por uma libido identitária que dificilmente poderia ser reduzida a um prosaico apetite financeiro, podendo mesmo ser contraposta a ele. Por fim, Galbraith (1993) lembra que a memória financeira é excepcionalmente curta, pois as novas gerações atuantes naquele espaço tendem sistematicamente a subestimar os riscos da "alavancagem" (como manifestação do conservadorismo de seus antecessores), o que produz um efeito sistêmico de conduzir periodicamente o mundo das finanças a situações de crise.

Inferimos, então, que o desabrochar e a necessidade de controle das novas gerações são traços permanentes do campo financeiro. É assim que, nesse início do século XXI, Dantas personifica as "novas gerações" para o público externo. Para o público interno, tudo indica que Armínio Fraga seja a principal referência (D'Ávila, 2004). Ambos cultivam o anonimato e a ascese, que os distingue de "arrivistas salientes" como Nahas (ou Edemar Cid Ferreira, não oriundo de "nação comerciante", mas de origem social modesta) e que, dessa forma, realça suas condições de patrícios. Mas Fraga consegue evitar a cena pública, exceto em condições propícias para afirmar seu patriotismo quando, por exemplo, disserta sobre os rumos da política monetária ou cambial sem anatemizar o governo Lula. Já Dantas parece bem mais avaro no que diz respeito a manifestações que revelem seu interesse público. Suas disputas empresariais são excepcionalmente salientes pelo ardor com que defende seus interesses exclusivos, levando a lógica financeira ao seu extremo. Em analogia ao campo artístico, ele faz o papel do enfant terrible, odiado por muitos e admirado por alguns. O futuro dirá se estamos diante de apenas de um simples narcisista (ou avaro) ou de um verdadeiro inovador da prática financeira. Mas, ainda que não exista uma prova nesse sentido, o episódio de seu depoimento na CPI mostra que ele é defendido com ardor por um conjunto 
grande de representantes públicos, o que denota que sua atuação pode ser justificável na esfera pública (Senado, 2005b).

\section{As responsabilidades sociais}

O relevo do campo financeiro revela-se, assim, mais rico e complexo. As diversas posturas e formas de legitimação indicam indivíduos e posições diferentes em concorrência, cujas interações diretas e indiretas dinamizam esse espaço e, dada a sua centralidade para a economia brasileira atual, acabam influenciando o espaço social como um todo. O conjunto dos grandes bancos comerciais, que à primeira vista parece distante dos nossos personagens, tem aplicado políticas sistemáticas de "responsabilidade social" e, mais recentemente, de "sustentabilidade", no sentido de t o má-los atores legítimos da ordem social brasileira, apesar dos juros e spreads estratosféricos que aplicam e cobram de seus clientes (Cruz, 2006). Diante da constatação dessa prática, eles alegam a excepcionalidade do momento vivido pela economia brasileira, corroída pela incerteza provocada por ações governamentais desastrosas. Uma vez "solucionadas" essas tendências, os bancos voltariam a seu papel tradicional de fornecer liquidez para os ciclos comerciais e de investimento, abandonando o papel de credores bem remunerados da dívida pública (Troster, 2004). Mesmo que o volume de aplicação e de lucro seja incomparavelmente maior do que o dos novos agentes, ainda que sejam os principais clientes da nova elite financeira, da qual solicitam a administração de carteiras de investimentos para atender suas clientelas mais sofisticadas (D'Ambrosio, 2003, 2004; Pavini, 2005), eles não personificam o mundo das finanças, como fazem nossos protagonistas "de vanguarda".

A responsabilidade social e a sustentabilidade podem ser consideradas novas tecnologias de intervenção privada em questões sociais e ambientais. Em primeiro lugar, elas elevam o patamar de efetividade da gestão da imagem pública e da legitimação de um número cada vez maior de empresas que as adotam (Sartore, 2006). Em segundo, re p resentam um novo espaço social, um lugar neutro, propício para a convergência das eli- tes. Elites empresariais encontram-se e põem-se de acordo com os representantes de ONGs encarregadas de operacionalizar as questões a serem atacadas, assim como com as lideranças sindicais presentes nos fundos de pensão que também coonestam esse desenvolvimento (Grün, 2005b). Por meio desse congraçamento, os setores estabelecidos restauram o balanço de re c i p rocidade social que a crise do Estado assistencialista levou de roldão ou as novas demandas que ele não consegue tratar. Nesse passo, restaura-se a hierarquia social apropriada para conferir deferência aos p a tronos das ações e estabilidade para sua pro eminência. Mas não é só isso: a libido que pede esse tipo de atuação corresponde a um habitus hie rá rquico alheio, até agora, aos nossos novos financistas. Nessa chave explicativa, não é surp reendente que Dantas e demais financistas pouco façam, ao menos publicamente, para preencher as novas funções do papel de dirigente de empresas estabelecido e responsável.

A oposição entre Dantas e os dirigentes dos fundos de pensão também pode ser explorada pelo lado das articulações em dois extremos do espaço financeiro. Mais do que qualquer outro evento, a ida de Lula à Bovespa, em 2002, jogou luzes na conexão que existia entre dirigentes dos fundos de pensão e setores menos dinâmicos do mercado financeiro, como os operadores tradicionais da Bolsa de Valores. De um lado, Lula ensaiava uma aproximação com os setores suscetíveis a apoiar suas propostas, objetivando evitar a intensificação da corrida contra o real, que poderia decretar um verdadeiro aborto de suas pretensões presidenciais ou de seu futuro governo (Murphy, 2002; Ripardo, 2002). De outro, os novos financistas claramente jogavam pela derrota do candidato do Partido dos Trabalhadores, "alertando" a população contra os riscos de ela ousar um voto rebelde, principalmente por intermédio de Soros, então convertido em seu ventríloquo (Gosman, 2002; Marques, 2002; Alencar, 2002; The Economist, 2002 ). No momento em que a eleição de Lula virou fato consumado, a necessidade (e a capacidade) de acomodação dos diversos atores passou a se fazer mais presente. Dantas e seus companheiros estavam mais comprometidos com o espírito do período anterior, e provavelmente também foram mais diretamente 
beneficiados do que outros atores. Dessa forma, para eles, o caminho da conciliação seria mais longo, mas nem por isso impossível ou impalatável (Valor Econômico, 2006; Recondo, 2006; Romero, 2005; Racy, 2006). Desvela-se aí mais uma característica do espaço financeiro. O habi tus local tende a conduzir a uma neutralização de paixões que possam pôr em risco as posições econômicas. Ainda que as paixões mexam com os indivíduos, os mecanismos locais forçam-nos a relevá-las. Para o indivíduo que habita o espaço financeiro, o homo oeconomicus não é simplesmente uma abstração heurística eficiente ou uma falácia empírica, mas sim um modelo de conduta legítima a ser perseguido. Porém, como qualquer identidade formada em tempos complexos, ele não opera livre e desimpedindo, mas se choca diferencialmente com a libido dominandi, que nesse contexto funciona como uma espécie de "lado negro da força"; ${ }^{12}$ e também com as novas sensibilidades, parcialmente legitimadas, de responsabilidade social e sustentabilidade, que, por sua vez, entram em tensão com a filantropia fulgurante promovida por atores como Soros.

\section{Uma nova elite?}

Outra característica do espaço aparece na localização geográfica dos nossos personagens notórios: tanto Fraga como Dantas mantêm a sede de seus negócios no Rio de Janeiro, invertendo uma tendência anterior de ver São Paulo como o centro das finanças do país, principalmente dos bancos comerciais, o setor "estabelecido" das finanças (D'Ávila, 2004; D’Ambrosio, 2004). Parte dessa situação pode ser explicada pela localização no Rio de Janeiro das escolas de economia mais identificadas com o pensamento ortodoxo (PUC-RJ; EPGE-FGV) (Loureiro, 1997) e também pelos investimentos correlatos em legitimação cultural da ordem financeira realizados por membros dessa nova elite. ${ }^{13}$ Afinal, os operadores financeiros dessa vanguarda são recrutados em sua maioria entre os economistas formados no Rio de Janeiro (e que passaram pela administração financeira do governo federal) do que entre os administradores e economistas formados nas "grandes escolas" paulistas da FGV e da USP, de alguma forma contaminados pelo espírito industrial do período anterior e mais presente na região. ${ }^{14}$ Essa separação geográfica torna mais fácil a diferenciação de padrões de sensibilidade e de atuação econômica e financeira, acrescentando maior complexidade ao campo do poder em âmbito nacional. Uma manifestação recente de força desse novo agrupamento foi justamente a passagem obrigatória de diversos aspirantes a adversário de Lula pela Casa das Garças (Balthazar, 2005; Cotta, 2006). Esse fato tornou evidente o papel de gatekeeping que esse novo grupo de financistaseconomistas exerce na relação entre o espaço financeiro internacional e o campo político brasileiro.

Na relação entre economia e tecnologia aparece outro traço marcante da visão de mundo do novo grupo e da atuação social que dela se depreende. Os anos de 1970 e 1980 foram marcados pela versão de que as economias industriais japonesa e alemã seriam arranjos sociais mais eficientes do que os anglo-saxões, fundamentalmente por causa da "concertação" de atores que elas ensejavam, permitindo a colaboração harmoniosa de esforços patronais, laborais e governamentais em torno de estratégias mais ou menos consensuais. Essa visão de excelência econômica ficou comprometida nos anos de 1990, quando os Estados Unidos passaram por um forte período de crescimento, ao lado da estagnação das duas outras economias. A primeira interpretação para este fato faz menção à liderança norte-americana de novas tecnologias na área de informática desenvolvidas no período. Os Estados Unidos dominavam a produção dos softwares e demais elementos da infra-estrutura informática e telemática - daí sua primazia. Essa versão foi questionada por outra, de fundo financeiro, segundo a qual a superioridade norte-americana residiria na maior capacidade de governança nos Estados Unidos por causa de seu mercado de capitais mais desenvolvido do que em outros países (The Economist, 1994). Não por acaso, essa versão foi encampada por nossos novos financistas, que passaram a advogar o desenvolvimento de um mercado de capitais brasileiro mais próximo do exemplo de sucesso norte-americano (Agestado, 2000). De um lado, seus investimentos culturais os predispõem a acatar tal versão; de outro, a expansão do 
mercado de capitais é, evidentemente, a situação social que melhor lhes convém para rentabilizar de modo mais efetivo o fundo de comércio já estabelecido. Uma conseqüência direta da predileção econômica e cultural é o tipo de estratégia que esse gênero de ator tende a empregar na gestão de empresas, em especial aquelas vistas como ineficientes, das quais as empresas estatais recémprivatizadas são o exemplo marcante.

Retomando a questão da responsabilidade social, pode-se fazer uma outra analogia com o campo artístico. As vanguardas costumam apresentar-se como o grupo que realmente cultiva e leva às últimas conseqüências os valores internos do meio, sem se deixar levar por compromissos espúrios. No caso da arte, a grande questãoreside no compromisso entre o desenvolvimento da lógica especificamente estética, de discernimento difícil para atores fora desse ambiente, como a clientela e os governos, e uma arte menos comprometida com a vanguarda. No nosso espaço mais prosaico, a questão da responsabilidade social, adotada decididamente pelos bancos tradicionais, aparece como um compromisso entre a lógica econômica e financeira e a necessidade de recip rocidade social que emerge das tarefas de legitimação geral da atividade financeira perante a sociedade. Compromisso necessário para aqueles que têm de se justificar para o mundo externo, mas uma atividade filosoficamente questionável para quem acredita nas virtudes sociais da endu rance p roduzida pela atividade econômica e vê no funcionamento desimpedido das leis da economia a melhor forma de regulação social possível. ${ }^{15}$

$\mathrm{Na}$ esfera internacional, essa questão é discutida num longo artigo publicado em 2005 na revista The Economist, em que o autor questiona a idéia de responsabilidade social em nome da visão econômica tradicional, segundo a qual a função da empresa é gerar lucros (Crook, 2005). Uma vez que os lucros são taxados pelos governos, que empregam esses recursos nas necessidades sociais segundo critérios mais abrangentes do que os que poderiam ser tirados do discernimento dos capitalistas, a alocação da reciprocidade seria mais bem realizada no âmbito governamental. A ousadia dessa revista, ao publicar um artigo que desafia uma tendência social já legitimada e apoiada por arautos muito fortes, foi retrucada por uma impressionante barragem de críticas, oriundas de profissionais da área de responsabilidade social, mostrando o enraizamento de "nosso enxerto" na paisagem social. ${ }^{16}$ Ficar de fora disso pode sair caro em termos de uma política inclusiva, mas representa um constrangimento identitário dificilmente evitável para o tipo de virtude que emana de ambientes como aquele em que se cria a nossa vanguarda financeira. Trata-se, assim, de um efeito de campo sociologicamente provável esperar que a vanguarda financeira se mantenha distante da responsabilidade social. Ao verificarmos a possível adesão de indivíduos ou empresas a esse tipo de atividade, talvez signifique sua "domesticação" pelo ambiente social inclusivo - a prosaica ascensão dos "indigitados" ao papel social de "estabelecidos".

Uma acusação constante, no tempo e no espaço, contra o mundo financeiro, associa essa atividade a jogos de azar. Como vimos, os banqueiros estabelecidos encontraram recentemente na responsabilidade social uma nova ferramenta para lidar com a questão da legitimidade; já as novas gerações tendem a usar nessa direção a tecnicidade ou profissionalismo de sua atividade (Mackenzie, 2006). Em termos da posição que ocupa cada um desses grupos, essa divisão faz sentido, já que os primeiros lidam muito mais freqüentemente com o grande público, ao passo que os últimos estão confinados ao pequeno mundo dos grandes investidores e das autoridades monetárias, os quais precisam ser convencidos da razoabilidade das complexas operações financeiras que nossa vanguarda propõe. No espaço das ações de benemerência que trazem legitimidade a seus protagonistas, observamos uma tendência internacional por parte dos titulares das novas grandes fortunas em adotarem posturas agressivas e individualistas, não por acaso análogas àquelas que empregam em seus negócios de origem. Soros é, mais uma vez, o exemplo flagrante, mas observamos um padrão análogo em outras "jovens fortunas", não necessariamente oriundas do setor financeiro (Strom, 2006; Miller, 1997; Guilhot, 2004, 2006). Vale lembrar que essas iniciativas, inusitadas e potencialmente controversas quanto ao objeto (por exemplo, doação de 1 bilhão de dólares de Ted Turner para a desacreditada ONU) e ao tipo de apoio (por exemplo, 
combate às posturas internacionais do presidente Bush patrocinado por Soros), passam ao largo do padrão do setor já constituído da responsabilidade social empresarial, o qual, em geral, patrocina causas que o bom-senso julga consensuais - certamente as causas defendidas por Soros e demais tycoons provocam tensões com o pólo estabelecido do setor (Miller, 1997; Blumenfeld, 2003).

Não havíamos observado esse padrão no Brasil, mas o exemplo internacional indicava que ele poderia apare cer. O depoimento de Dantas na CPI revelou que ele e seu grupo também desenvolvem projetos na área da educação. Respondendo sobre seus contatos com integrantes do gove mo Lula, afirmou que seu interlocutor mais $\mathrm{f}$ reqüente foi:

O Ministro Cristovam Buarque. Estávamos levando a ele um projeto que fizemos para a Educação, que era um projeto basicamente para tentar aproveitar um pouco da tecnologia gerencial privada e tentar desenvolver práticas de custo mais baixo para que fosse possível educar a um custo menor. $\mathrm{Na}$ verdade, de qualquer jeito, mesmo que haja verbas suficientes para a educação, se for possível gastar menos, é sempre melhor. Temos um instituto de desenvolvimento de práticas onde foi desenvolvido um programa em que basicamente há um pagamento, uma remuneração por cada aluno - aprovado numa prova feita pelo Estado ou por um órgão independente - mas quem ganha é o professor. E o professor ganha por aluno aprovado. Isso criou uma grande motivação; o conteúdo de educação é um conteúdo preparado, um conteúdo de alto conteúdo didático. Você não precisa de proficiência, do ponto de vista dos professores (Senado, 2005a).

Independentemente da qualidade intrínseca da solução que ele aponta para problemas educacionais, este iconoclasta atenta contra as formas estabelecidas de remuneração e de motivação de professores, propondo incentivos típicos do universo financeiro. Podemos ser contra ou a favor da forma e do conteúdo da intervenção de Dantas na esfera educacional, mas temos de reconhecer que ela é controversa, aproxima seus patrocinadores do "padrão Soros" e, conseqüentemente, afasta-os do estilo "bom-moço" das ações de responsabilidade social padronizadas. Vemos, assim, o habitus tycoon agindo no Brasil contemporâneo também na esfera da benemerência.

\section{O campo financeiro}

As tensões internas do espaço financeiro, ao lado das cooperações diretas e indiretas, mostram a existência de um espaço em que as estratégias e os valores (monetários, sem dúvida, mas, como vimos, também simbólicos) são comparados e retroalimentados. Mais uma vez em analogia com o campo artístico, vale lembrar que os produtos da atividade financeira estão longe de obterem valor consensual na sociedade. Assim como a obra de arte, eles dependem de uma alquimia social complexa para ganharem verossimilhança (Mackenzie, 2001). Alquimia esta produzida primeiro no próprio espaço financeiro - talvez resida aí a principal fonte de solidariedade interna, que predispõe a maioria dos players a coonestar os artefatos produzidos pelos colegas/concorrentes, e praticamente obriga todos agentes a não ficarem indiferentes às obras dos outros, seja para aceitá-las, seja para refutá-las. O alargamento recente desse espaço, propiciado pela entrada das elites não-financeiras, tornou $\mathrm{O}$ processo ao mesmo tempo mais complexo e mais eficiente: um investimento ou instrumento financeiro utilizado por um fundo de pensão torna-se mais verossímil, assim como um projeto industrial ou de intervenção social endossados por uma ONG pré-legitimada por atuações conhecidas pelo público. A conquista das adesões de agentes externos à ordem e à lógica financeiras é um processo de negociação custoso, mas parece representar uma tendência irreversível na cena atual (Camba, 2005). Como nas gravuras japonesas, os produtos financeiros passam por uma cadeia de endossos que lhes fornece o selo de qualidade; é difícil conseguir mais endossos, mas cada novo atestado, investindo o capital simbólico do endossante, acrescenta qualidade e segurança ao produto. É assim que, corroborando essa tendência, apareceram recentemente não só o Índice de Sustentabilidade Empresarial - ISE, como também um novo produto, qual seja, a gestão de risco de carteiras administradas pelos novos gestores, efetuada pelos grandes bancos estabelecidos (Vieira, 2006). Em planos bem distintos, as duas evoluções ajudam a soldar a cada vez mais longa cadeia de construção recíproca de verossimilhanças e de interdependência que produz a legitimação da ordem financeira. 
Mas os endossos também não custam barato. Os endossantes tensionam suas posições em seus respectivos universos de origem. As ONGs cresceram em grande parte a partir de opções de militância esquerdista, e o pragmatismo de alguns continua sendo repudiado por outros. No caso recente do ISE, vimos o Instituto Brasileiro de Análises Sociais e Econômicas - Ibase sair da comissão que o estava estabelecendo por discordar da inclusão de empresas que produziam produtos considerados nocivos, como, por exemplo, tabaco (Pavini, 2005). Para os sindicalistas gestores dos fundos de pensão, é sempre audível a voz daqueles que os lembram que vários dos empreendimentos em que investem não são exemplo de boas práticas trabalhistas ou que, mais doutrinariamente, condenam o sistema de aposentadoria por capitalização, promovido pelos fundos. ${ }^{17} \mathrm{Em}$ ambos os casos, os atores que aceitaram jogar o jogo da legitimação cruzada respondem dizendo que a sua presença naqueles universos possibilita a "domesticação das tendências agressivas do capital”. E como essa configuração é recente, as conseqüências ainda não foram provadas: nos empreendimentos apoiados pelos fundos de pensão ou coonestados pelo ISE, por exemplo, não ocorreu ainda nenhum escândalo trabalhista ou ambiental, mas isso não quer dizer que não tenha já ocorrido fatos que mereceriam o repúdio da sociedade. A calmaria tanto pode significar o cumprimento da promessa de domesticação, como a incapacidade dos militantes contrários à convergência de criar um clamor público necessário para fazer a sociedade conhecer eventos e situações que atentariam contra a moral dominante na sociedade ou no seu espaço de atuação particular. ${ }^{18}$

Talvez encontremos aí outro ponto que alimente nosso argumento em relação a Daniel Dantas. Até onde as informações públicas indicam - e nessa rubrica são elas que contam -, ele não participa do circuito longo de legitimação que aparece para o público externo. Ademais, seu contencioso com os fundos de pensão e com o governo Lula, além de produzir estragos na imagem do setor financeiro como um todo - por tornar uma disputa comercial pública e cheia de ingredientes de novela policial -, ajuda a dourar o brasão dos representantes dos trabalhadores nos fundos, sugerindo que sua ação "domestica- dora" está sendo efetivamente realizada. No cerne da justificação apregoada pelos dirigentes dos fundos de pensão, a imagem de plutocrata ligada a Daniel Dantas é um suporte ideal para referendar a idéia de que eles funcionam efetivamente como controladores do potencial destrutivo dos mercados financeiros, não só no espaço econômico, mas também na esfera cívica. Nas palavras de Fernando Ferro (PT-PE):

V. Sa [referindo-se a Daniel Dantas] faz parte de um grupo que, no Governo Fernando Henrique, junto com os Mendonça, Pérsio Arida e Elena Landau, constituiu um núcleo político e ideológico para se apropriar de uma parcela do Estado brasileiro. O processo de privatização foi uma investida no patrimônio do País para atender grupos de que V. Sa faz parte. E para fazer isso, usouse dos expedientes políticos da interferência, das ações políticas, da pressão do Presidente da República, de aliados, até da (Inaudível.), que no final foi utilizada para esse tipo de ação política (Senado, 2005b).

Assim, querendo ou não o indivíduo de carne e osso que lhe dá suporte, o nosso "totem" adquire uma força simbólica ainda maior. Sua face "maligna" é invocada sistematicamente pelos sindicalistas e políticos inseridos no circuito financeiro que se justificam como promotores do com merce doux redivivo. Mas a polissemia está sempre presente, fertilizando nosso símbolo, pois há aqueles que acreditam que os fundos de pensão não passam de um braço disfarçado do execrado corporativismo getulista. Nessa chave, o mesmo papel dos fundos de pensão é visto negativamente, e Dantas ganha o status de herói civilizador, que ousa manter a luta contra o que seus cultuadores julgam ser um anacronismo que teima em manter-se vivo no mundo globalizado. ${ }^{19}$ Nas palavras do senador César Borges (PFL-BA), também expressas no depoimento em 21/9/2005: "É um empresário de sucesso. E, hoje, acho que ele é até mais que um empresário, passa a ser um mito, em nível nacional, diante dos seus negócios, e a controvérsia sobre muito desses negócios”.

Quando inquirido sobre as fontes de seu sucesso empresarial, em especial, sobre o quê justificaria ser ele o operador do processo de privatização, Daniel Dantas, além de proverbialmente omitir as respostas sobre as condições sociais de 
seu sucesso (pergunta feita muito claramente por Gastão Vieira - PMDB-MA), qualifica-se afirmando que

[...] na época que montei o Opportunity, tínhamos o fundo mais rentável do mundo. O Opportunity tinha ganho quase todos os prêmios por ter sido um fundo extraordinariamente rentável. Eu já tinha passado por várias experiências na área de investimento: fui diretor do Bradesco, fundei o Banco Icatu, tínhamos uma empresa de participações, já tinha passado por muitos negócios.

Sobre a inovação que estaria trazendo à economia brasileira, ele afirma:

Eu, em conjunto com os representantes do Citibank, fomos ao Governo brasileiro, inicialmente ao Presidente Fernando Henrique Cardoso, e pedimos e sugerimos que, se fosse possível, criar uma linha e uma estrutura que pudesse apoiar esse tipo de iniciativa. Fizemos uma primeira explanação do que se tratava esse tipo de fundo, que, em inglês, chama-se um fundo de private equity, mas, como acho melhor usar o termo em português, se pudesse arriscar uma tradução, um fundo de participações privadas. Hoje, nos países desenvolvidos, esse talvez seja a grande mola do capitalismo inovador nos Estados Unidos e na Europa. Existe mais ou menos US $\$ 1$ trilhão investidos nesses fundos. Toda a costa oeste americana é povoada de iniciativas que são fomentadas por esse tipo de estruturas, que são especializadas em captar recursos institucionais e aplicar recursos fomentando empreendedores, empresas, quer viabilizando novas iniciativas, quer mudando a equação gerencial de iniciativas já existentes, ou seja, reestruturando operações que já existiam (Senado, 2005b).

\section{A "mãe das novidades"?}

Voltando à análise geral do campo financeiro, é interessante notar que os "fundos de private equities" são realmente considerados uma inovação importante, tendo sido inclusive "apadrinhados" pelos órgãos financeiros internacionais como um dos principais instrumentos que as economias em desenvolvimento devem se dotar para acelerar virtuosamente o seu crescimento. Não é assim por acaso que o governo brasileiro assinou acordo com o FMI comprometendo-se a estabelecer uma legislação específica para regulamentar essa novidade (Valor Econômico, 2003). Vejamos: de um lado os agentes financeiros privados propõem a inovação para resolver a questão do financiamento das privatizações, o que resolveu um dos maiores problemas do governo anterior; do outro, os órgãos internacionais insistem no estabelecimento das condições institucionais para criar um mercado mais seguro, ajudando na generalização do novo produto financeiro, do qual nossos agentes privados são os especialistas confirmados.

Num outro plano, de história das idéias, notemos que a lógica que rege os "fundos de pri vate equity" representa uma forma de acumulação de recursos e de repartição de lucro e risco já conhecida desde os primórdios do capitalismo, tendo sido usada, por exemplo, pelos armadores para financiar as grandes navegações. No Brasil, grupos étnicos, religiosos e elites locais promoveram diversos empreendimentos a partir desse princípio, em especial a construção de edifícios. Mas essas empreitadas, baseadas numa lógica social da confiança "pré-capitalista", estão limitadas aos espaços sociais protegidos dos quais emergiram. Os inovadores financeiros dos tempos atuais são capazes de produzir as condições institucionais (de início, como vemos, as estritamente jurídicas; resta saber se também no plano da taked-for-granted-ness) que generalizam e normalizam aquelas práticas.

Assim, ao falarmos de "inovação" no setor que estamos analisando, é importante ter em mente que uma boa parte do jogo se trava na esfera política, reforçando a idéia de que o campo financeiro é uma parte do campo do poder. E aí aparece outra característica desse mundo das finanças: as habilidades sociais necessárias para os agentes financeiros trafegarem eficientemente no espaço político não são enunciadas como tais, nem suas idéias como políticas. Pelo contrário, ao investirem sobre o campo político, eles aparecem como empreendedores e suas idéias como uma espécie de "senso comum" da modernidade. Assim, eles "não fazem política" no sentido pejorativo que a atividade ganhou nos últimos tempos. Ao contrário, para seus partidários, eles merecem ser celebrados porque conseguem vencer as barreiras que o mundo da política impõe à sociedade, ajudando-a a evoluir. Para muitos de seus inimigos, como vimos na CPI, eles encarnam 
Lúcifer. Aí aparece outro ardil da dominação financeira. Enquanto os detratores atacam os atores da estirpe de Daniel Dantas acusando-os de não só fazerem política como também de corromper profundamente aquele espaço cívico, a sua defesa se organiza em torno do argumento de que eles não só não são políticos, mas encarnando a racionalidade econômica, eles são o próprio motor do progresso da sociedade. Assim, a batalha cultural das representações se concentra em torno da aceitação, ou não, da atuação dos financistas como política ou econômica. A vencer a primeira, eles teriam complicações à frente. Ao contrário, se prevalece a segunda interpretação, sua ação ganha espaços ilimitados.

\section{Conclusão}

À primeira vista, o espaço das finanças parece um universo fechado, impenetrável para a análise sociológica. Creio que nossas aproximações em torno de certas figuras, produzidas pela relação tensa existente entre aquele universo e a sociedade, tenham ajudado a diminuir tal impressão. Com base apenas em fontes públicas, parte do espaço se torna visível e sociologicamente compreensível. A parcialidade dessa compreensão é evidente, mas só poderá ser realmente avaliada quando confro ntada a outras tentativas de objetivação sociológica desse espaço. Seriam nossos "plutocratas" realmente uma boa entrada para um universo de práticas e hábitos tão esotéricos? Ou seriam apenas epifenômenos que mascaram as tendências mais importantes? Outros pontos de vista, outras ferramentas teóricas e outras fontes matizariam (ou invalidariam), provavelmente, a presente análise, estimulando pesquisadores e estudantes a investigar esse espaço tão vital para a sociedade, mas tão pouco estudado pela sociologia.

Neste artigo, tentei "abrir a caixa preta" das finanças, procurando encontrar algumas das fontes sociais de sua dinâmica interna e de suas relações com outros universos. Obviamente existe uma complexidade muito maior do que deixa entrever a fresta que explorei aqui. Alguns estudiosos procuram entender, de maneira sistemática, a lógica da eficácia dos instrumentos financeiros modemos, em geral com base teórica nos Estudos
Sociais sobre as Ciências (Mackenzie, 2001; KnorrCetina e Bruegger, 2002; Beunza e Stark, 2004). Outras contribuições, geralmente trazidas por pesquisadores que antes se ocupavam da sociologia das organizações, tentam dar conta sociológica do novo ramo da economia financeira, que transformou significativamente o escopo da área econômica, fazendo do economista um especialista em arbitragens a partir da exploração de "falhas de mercado", e também apontam para o interessante caráter perf o mático dessa ciência social, que fica cada vez mais evidente conforme a transformação p rofissional vai se aprofundando (Perrow, 1990; Fligstein e Friedland, 1995; Grün, 2004a e b; Mackenzie, 2006). Esses veios riquíssimos podem (e precisam) ser explorados de diversas formas nessas terras povoadas por Chicago Boys. Apenas entrevi essa possibilidade na apresentação sumaríssima das private equities. A "construção social” da verossimilhança e do mercado dessa nova (e velha) entidade aparece muito nítida e, dada a sua centralidade na montagem das operações financeiras que reconstrem a paisagem econômica contemporânea, torna-se necessário conhecer a dinâmica da qual ela é produto e que, por sua vez, é capaz de deflagrar ou aprofundar.

Um outro tema que apareceu em diversos pontos da análise é o da "responsabilidade social das empresas" e de sua relação com as formas de intervenção social e de construção de legitimidade inspirada pelos enfants terribles das finanças e demais setores dinâmicos da economia. As duas atividades costumam ser vistas no mesmo bloco, com base na diferenciação referente à tradicional ação social sob controle direto dos Estados. Contudo, esta análise mostra que se trata de pólos antagônicos, já que funcionam a partir de lógicas diferentes e concorrentes. É necessário, portanto, observar as fontes de tensão causadas pela coexistência desses dois fenômenos, apenas parcialmente recobertos pela mesma rubrica. Afinal, mesmo que eles não atinjam diretamente uma parcela muito relevante da paisagem social, é indisfarçável sua pretensão de influir na ação governamental de maneira direta ou, pelo menos, causar algum efeito sobre as estratégias de políticas públicas.

Os nossos "plutocratas" tornam-se figuras públicas a partir do que, provisoriamente, chama- 
mos de "escândalos". ${ }^{20}$ Segundo os estudiosos que se ocupam das técnicas de "escandalização", a melhor maneira de medir o sucesso dos empreendedores morais que se utilizam do escândalo como forma de fazer avançar seus propósitos é o impacto produzido na cena pública, alterando, ou não, procedimentos, leis, hábitos e costumes. Periodicamente, a sociedade brasileira ensaia "escandalizar-se" com algumas conseqüências da dominação financeira, como, por exemplo, os lucros e as margens do sistema bancário, mas pouco se faz efetivamente para alterar o preço da intermediação financeira. Seguindo essa lógica, poderíamos dizer que os protestos antifinanceiros são produzidos por uma coalizão de empresários, sindicalistas e intelectuais tradicionais que se insurgem contra o que consideram ser o maior impedimento ao desenvolvimento econômico do país. Mas eles são neutralizados pelos empreendedores morais da "causa financeira" - economistas mainstreamers e pelo establishment -, que os ridicularizam, esvaindo qualquer possibilidade de protesto mais eficiente. Novos anúncios sobre os resultados financeiros dos bancos, o acaso da publicação de algum estudo sobre o spread bancário, ou, ainda, uma tentativa de criar ou de esvaziar algum escândalo ligado a problemas financeiros, quaisquer desses fenômenos reproduziriam a discussão anterior. Previsivelmente, elas também seriam enquadradas pelos novos guardiões da racionalidade societária. Duas possibilidades podem ser extraídas dessa aparente abulia: a primeira, mais concreta, é que a sociedade brasileira já naturalizou a dominação financeira; qualquer abalo nessa ordem simbólica seria rapidamente controlado pelos "intelectuais da ordem". A segunda, menos evidente, indica que esse movimento periódico das marés está produzindo um novo formato da estrutura simbólica da sociedade, criando categorias para expressar as sensibilidades antifinanceiras.

\section{Notas}

1 Este artigo tem por base análises mais microsituadas de como o mundo fabril se dobra ao predomínio financeiro (Grün, 1999); do espaço organizacional e da transformação da sua relação com o mercado de capitais (Grün, 2003a, 2005a e b]); algumas relações internas ao mercado financeiro e suas conseqüências no espaço político (Grün, $2004 a$ e b). Dessa forma, a possibilidade de ensaiar uma análise específica da dinâmica cultural da dominação financeira nutre-se do conhecimento sobre o espaço das finanças, seus instrumentos de ação econômica e social e de suas relações com outros setores.

2 Evidentemente, o que interessa para a análise sociológica da cultura financeira é a imagem e o personagem Daniel Dantas, e não o indivíduo.

3 Segundo uma biografia oficial, Armínio Fraga foi presidente do Banco Central do Brasil de março de 1999 a dezembro de 2002. Anteriormente, ocupou durante seis anos o cargo de Diretor Gerente da Soros Fund Management LLC em Nova York. Entre 1991 e 1992, Fraga foi Membro da Junta de Diretores e Diretor do Departamento de Assuntos Internacionais do Banco Central do Brasil. Também trabalhou em Salomon Brother em Nova York e no Banco de Investimentos Garantia, no Brasil, e foi professor na Escola de Assuntos Internacionais da Universidade de Colúmbia, na Escola Wharton e na Universidade Católica do Rio de Janeiro. Atualmente, ministra cursos na Escola de Pós-graduação em Economia da Fundação Getúlio Vargas no Rio de Janeiro,. Doutor em Economia pela Universidade de Princeton, Fraga formou-se como bacharel e fez mestrado em Economia na Universidade Católica do Rio de Janeiro em 1981. Além disso é membro de prestigiosas organizações internacionais, como o Grupo dos Trinta, o Conselho de Relações Internacionais, a Junta de Assessores ao Presidente do Foro de Estabilidade Financeira, a Junta Assessora de Pesquisas do Banco Mundial, o Diálogo InterAmericano e a Junta de Diretores de Pro-Natura (Estados Unidos).

4 A partir desse momento, um caminho analítico paralelo leva em conta a mídia enquanto campo, suas relações com outros espaços sociais, como o da política e do Judiciário, e as razões internas de cada um deles na formação desse "totem". Aí, o foco são os constrangimentos internos de cada espaço - a competição e a colaboração entre profissionais, entre empresas, as relações entre os primeiros e os segundos, bem como a competição e a colaboração entre a mídia e outros subespaços que compõem o que Bourdieu (1989) chama de campo do poder. A esse respeito, ver Grün (2006).

5 Nomes costumam migrar mais facilmente do que conteúdos estruturados, já que permitem flexões 
locais de sentido que afetam pouco a legitimidade do rótulo importado. Dessa forma pudemos observar a importação recente da "ferramenta" governança corporativa no Brasil, um rótulo legítimo e poderoso no mundo empresarial e financeiro, mas que aqui serve para "consertar" situações diferentes daquelas que aparecem na cena original estadunidense.

6 A transcrição taquigráfica do evento foi acessada em 23/8/2006 no site http://www.senado.gov.br/ sf/atividade/Comissoes/consComCPI.asp?com=13 35. A sessão também foi integralmente filmada pela TV Senado, disponível sob pedido (Senado, 2005b). A observação das posturas do depoente, seu séqüito e dos parlamentares durante o depoimento possibilita uma socioanálise das formas verbais e gestuais de se fazer importante nos espaços financeiro e político e seus efeitos sociais. Uma das manifestações mais eloqüentes do desvelamento da estrutura social que ocorreu no episódio foi a fala de Zulaié Cobra (PSDB-SP): "A minha pergunta, Sr. Daniel Dantas - eu já vi que Daniel Dantas é como todo rico: fala baixo. Eu preciso ser um pouco mais rica e falar baixo. Gente pobre fala muito alto. É uma desgraça! Vou fazer um curso para falar baixo (Senado, 2005a).

$7 \mathrm{Na}$ mesma chave, constatamos que imagem pública do grupo Votorantin - sempre lembrado como o mais importante conglomerado industrial brasileiro - não é enfocada por sua presença no mundo financeiro, , apesar da grande importância que tem o Banco Votorantin no portfólio do grupo. Não é à toa que seu dirigente mais conhecido, Antônio Ermírio de Morais, é visto e festejado como "campeão" da indústria brasileira.

8 Deparei-me com esse traço da sociedade brasileira num outro objeto completamente diferente: as formas como políticos de origem judaica se inserem no espaço do seu ofício (Grün, 1994). O que une os dois espaços é o fato de ambos serem espaços públicos, onde os agentes sociais acionam, e testam, os diversos recursos retóricos disponíveis na sociedade. A soma das evidências dá segurança à afirmação do caráter pouco importante do anti-semitismo no Brasil.

9 Não significa que a ousadia seja apanágio de indivíduos de origem "patrícia", mas que estes pagam preços menores por ela não só na legitimação de seus atos mas também no custo de eventuais fracassos.

10 O volume de recursos mobilizado por Nahas nas ações bursáteis também denota o uso extremo da "alavancagem", mas num contexto em que sua legitimidade era mais precária, fragilizando o per- sonagem e, muito provavelmente, levando-o à derrocada.

11 É justamente nesse ponto que seus concorrentes intervêm na esfera jurídica, impugnando o uso que Daniel Dantas faz dos recursos que administra como delegado (Mendes, 2006). O desfecho desse contencioso pode ser entendido como uma prova de laboratório da aceitação social ou da reprovação das práticas "vanguardistas" no espaço econômico.

12 Lordon (2002) explora sistematicamente a disputa por controle entre os grandes bancos franceses. A variação das justificativas de cada um mostrou a plasticidade da "lógica" econômica, claramente transformada em uma retórica complacente e subsumida pela libido dominandi. No nosso espaço empírico, as constantes acusações sobre os atos de espionagem de DD/Kroll podem ser catalogadas como essa libido dominandi transfigurada em "necessidade de conhecer os próximos passos de nossos adversários".

13 O mais interessante é o Instituto de Estudos de Economia Política, conhecido como a "Casa das Garças" (ver site http://iepecdg.com/DISK 1/paginaquemsomos.html). Não por acaso, os candidatos a adversário de Lula nas eleições de 2006 passaram pela "sabatina" do grupo (Gois, 2006a e b).

14 Evidentemente, a gênese desse "efeito de aglomeração" merece uma explicação em si mesma. Ainda que não comprovada, é sedutora a hipótese de que estejamos diante de algum tipo de continuidade do padrão da economia pré-industrial, em que a produção agrícola era efetuada no interior de São Paulo, enquanto as operações financeiras correlatas (opções de futuro, empréstimos e adiantamentos etc.) eram realizadas no Rio de Janeiro ou em Santos. Mas, de qualquer maneira, creio ser lícito inferir que a continuidade do predomínio financeiro na economia e na sociedade tenderá a alinhar o ensino de economia e administração de São Paulo com a nova realidade.

15 Sobre a lógica mnemônica do raciocínio que faz nascer a virtude a partir da rigidez econômica, ver Lakoff ( 1996).

16 Para as críticas e as discussões em torno dessa questão, ver o site http://www.economist.com/ surveys/displaystory.cfm?story_id=3574392.

17 Na "capitalização", cada participante do sistema tem uma conta particular que acumula suas prestações, as do seu empregador e os rendimentos delas (a capitalização), e o montante que 
ele receberá quando aposentado será calculado a partir dos resultados financeiros dessa acumulação individual. Na "repartição", os trabalhadores de uma geração "X" pagam as aposentadorias dos seus antecessores (geração "X-1"), que são atribuídas por critérios de justiça social e esperam que seus sucessores no mercado de trabalho (geração "X+1") façam o mesmo em relação a eles. Esse sistema é considerado mais eficiente em termos de manter a coesão social, ao passo que o primeiro é considerado melhor para induzir o desenvolvimento econômico, pois geraria excedentes em posse de particulares para serem investidos em negócios lucrativos. A quase totalidade dos atores contemporâneos considerados especialistas no tema é partidária da "capitalização”, embora haja uma oposição, em geral advinda do catolicismo social europeu, que corrobora a crítica que muitos sindicalistas fazem do sistema (Nikonoff, 1999). Mais recentemente, a evidência de sérias crises em fundos de pensão tradicionais parece estar alterando a "doxa" prócapitalização para posicionamentos mais nuançados (Virard, 2006; Olmos, 2003; Grün, 2005).

18 Os estudos sobre mobilização mostram que para "criar um escândalo" é necessário capacidade e tecnologia específicas - "saber e poder" - que refletem as assimetrias na distribuição de capitais social e cultural (Champagne, 1984; Garrigou, 1993; Neveu, 1996) . Dessa forma, o fato de não haver escândalos pode indicar não só, ou simplesmente, a complacência moral da sociedade em relação ao evento em questão, mas também o enfraquecimento daqueles que se sentem incomodados por ele (De Blic, 2005).

19 Além da atuação recente da "bancada Daniel Dantas" no Congresso Nacional, manifestações de integrantes do governo FHC mostraram que muitos agentes daquela constelação partilham da idéia, ainda que os fundos sejam considerados cidadãos de pleno direito da república internacional das finanças (Futema, 2002; Grün, 2003a).

20 Os escândalos produzem ondas de choque que vão bem além das intenções de seus deflagradores e expressam as próprias dinâmicas culturais e sociais a que estamos submetidos. No caso do "mensalão", vimos surgir algo inesperado: a reprovação social ao processo de privatização das empresas estatais, empreendido durante a presidência de Fernando Henrique Cardoso. A esse respeito, ver Grün

\section{BIBLIOGRAFIA}

AGESTADO. (2000), "Fraga: governo incentivará fundos de pensão". Agestado, despacho, $7 / 9$.

Agulhon, M. (1990), La République. Paris, Hachette (col. Histoire de France)

ALENCAR, K. (2002), "Armínio não quis fazer terrorismo eleitoral, afirma ministro a petista". Folha de S.Paulo, 12/10.

ANGELO PAVINI, C. V. E. L. M. (2004), "Nova safra de fundos: gestoras independentes lançam carteiras arriscadas. Valor Econômico, 17/2.

ATTUCH, L. (2004), "Nahas absolvido... e com sede de vingança: quinze anos depois do estouro da Bolsa de Valores, o megainvestidor Naji Nahas livra-se da acusação de crime ao sistema financeiro, volta a operar, prepara ações na Justiça contra inimigos e quer reinar novamente no mercado". Istoé Dinbeiro, 9/6.

BALTHAZAR, R. (2005), "Serra Critica PT e Tesouro por acordos políticos". Valor Econômico, 12/5.

BEUNZA, D. \& STARK, D. (2004), "Tools of the trade: the socio-technology of arbitrage in a Wall Street trading room". Industrial and Corporate Change, 13 (2): 369-400.

BIRNBAUM, P. (1979), Le peuple et les gros: histoire d'un mythe. Paris, B. Grasset.

BLAIR, M. M. (2003a), "Reforming corporate governance: what history can teach us: Georgetown University Law Center". Research Paper, n. 485663.

(2003b), "Shareholder value, corporate governance and corporate performance: a post-Enron reassessment of the conventional Wisdom", in P. K. C. A. B. Kogut (ed.), Corporate governan ce and capital flows in a global econo$m y$, Oxford, Oxford University Press. 
BLUMENFELD, L. (2003), "Soros's deep pockets vs. Bush: financier contributes $\$ 5$ million more in effort to oust president". Washington Post, 11/11.

BOURDIEU, P. (1989), La noblesse d'état: grandes écoles et esprit de corps. Paris, Minuit (col. Sens Commun).

. (1992), Les règles de l'art: genèse et structure du champ littéraire. Paris, Seuil (col. Libre Examen. Politique).

(1997), Méditations pascaliennes. Paris, Seuil.

CAMBA, D. (2005), "O que é ser socialmente responsável? Entidades e empresas travam batalha para definir critérios que deixariam ações de fora do Índice de Sustentabilidade em preparação pela bolsa". Valor Econômico, 30/3.

CARIEllO, F. D. B. E. S. e. R. (2006), “A política interna se tornou irrelevante, diz sociólogo Francisco de Oliveira". Folha de São Paulo, 24/7.

CARTA CAPITAL. (2005), "O Sinhozinho: Heráclito Fortes agride repórter do Piauí que quis saber sobre seu apoio a Dantas". Carta Capital, 31/8.

CARVAlHO, M. C. (2006a), "Edemar é acusado de desviar verba para arte: Procuradoria afirma que ex-banqueiro usou dinheiro de clientes para bancar exposições como a de Picasso; advogado nega". Folba de São Paulo, 18/6.

, (2006b), "José Safra assume controle do Banco Safra". Valor Econômico, $25 / 7$.

CATHERINE VIEIRA, H. M. E. T. C. (2004), "Ministro diz que PF descobriu, desde março, indícios de apuração ilegal, não autorizada pela Justiça: espionagem pode fortalecer fundos de pensão". Valor Econômico, 23/7.

CHAGAS, Helena. (2005), "Briga empresarial ajudou a pôr Dirceu e Gushiken em campos opostos". O Globo, 31/7.
CHAMPAGNE, P. (1984), "La manifestation: la production de l'événement politique". Actes de la Recherche en Sciences Sociales, 5253: 18-41.

COFFEE, J. C. (2002), Understanding Enron: it's about the gatekeepers, stupid. Columbia, Columbia Law School, The Center for Law and Economic Studies, Working Paper, n. 207.

COHEN, B. H. (2002), "Capital controls: why do governments hesitate?", in L. E. Armijo (ed.), Debating the global financial architecture, Albany, State University of New York Press.

COTTA, E. (2006), "A economia segundo Alckmin: escolhido pelo PSDB, Alckmin promete choque de gestão, menos impostos e acena com um BC independente. O mercado comemora". Istoé Dinbeiro, 22/3.

CROOK, C. (2005), "Survey: corporate social responsibility. The good company. The movement for corporate social responsibility has won the battle of ideas. That is a pity". The Economist, 20/1.

CRUZ, N. H. D. (2006), "Levantamento com 107 países mostra que, além de ter maior taxa básica, Brasil lidera também na taxa ao consumidor: bancos do país cobram maior juro do planeta". Folha de São Paulo, 16/2.

DIAS, L. (2000), "Realeza no green: o que acontece quando os nobres da economia e finanças se encontram entre uma tacada e outra". Istoé Dinheiro, 8/12.

D’AMBROSIO, C. V. E. D. (2003), "Fundos multimercados voltados para o público de alta renda se multiplicam em velocidade espantosa: quase um novo produto é lançado por dia: os novos vips". Valor Econômico, 16/10.

. (2004), "Independentes com patrimônio de R\$ 1 bi: clube do bilhão". Valor Econômico, 19/1. 
DARNTON, R. (1986), "Dialogue à propos de l'histoire culturelle: entretien avec Pierre Bourdieu et Roger Chartier". Actes de la Recherche en Sciences Sociales, n. 59, pp. 86-93.

D’ÁVILA, S. (2004), "República do Leblon cresce e aparece". Folha de São Paulo, 18/1.

DE BLIC, C. D. A. L. (2005), "Le scandale comme épreuve: éléments de sociologie pragmatique". Politix, 18 (31): 9-38.

DINIZ, A. F. (1996), As representações do encilha mento. São Paulo, Dissertação de mestrado, FFLCH, USP.

ÉPOCA ONLINE. (2002), "Armínio Fraga pode ficar na presidência do BC até 2003”. Época Online, 13/11.

FLIGSTEIN, N. \& FRIEDLAND, R. (1995), "Theoretical and comparative perspectives on corporate governance". Annual Review of Sociology, 21: 21-43.

FOLHA ONLINE. (2006), "Jefferson diz que foi procurado por Dantas para denunciar PT". Folha Online, 30/5.

FUTEMA, F. (2002), "Ex-ministro diz que $P$ revidência 'afrouxou' a fiscalização dos fundos". Folha de S.Paulo, 4/6.

GALBRAITH, J. K. (1993), A short bistory of finan cial euphoria. Nova York, Whittle Books in Association with Viking.

GARRIGOU, A. (1993), "Le scandale politique comme mobilisation", in F. Chazel (ed.), Action collective et mouvements sociaux, Paris, Presses Universitaires de France.

GASPARI, E. (2002), "O cavalheiro Armínio Fraga". Folha de São Paulo, 11/12.

GATES, M. N. (2003), "The Sarbanes-Oxley Acr and non-US issuers: considerations for international companies". Journal of Commercial Biotechnology, 10 (1): 40-53.

GINZBURG, C. (1991), "Représentation: le mot, l'idée, la chose". Annales ESC, pp. 12191234.
(1992), "Just one witness", in S. Friedländer (ed.), Probing the limits of representation: nazism and the "final solution". Cambridge, Mass., Harvard University Press.

(1989), "The wolf-man and the werewolves", in______ (ed.), Clues, myths, and the historical method. Baltimore, Md., Johns Hopkins University Press.

GOIS, A. (2006a), "Aliás...". O Globo, 21/2.

(2006b), "Passou na PUC". O Globo, $21 / 2$.

GOODY, J. (1997), Representations and contradictions: ambivalence towards images, theatre, fiction, relics, and sexuality. Cambridge, Mass., Blackwell Publishers.

GOSMAN, E. (2002), "Polemica intervencion del multimillonario Hungaro Soros también dispara sobre Lula: el célebre financista advirtió que si gana Lula, Brasil entrará en 'caos'. En declaraciones a un diario brasileño, Soros señaló que 'los mercados se calmarán' si gana José Serra, el candidato oficialista". Clarin, 9/6.

GRÜN, R. (1994), "Identidade e política: os judeus na esfera pública e a representação da comunidade". Revista Brasileira de Ciências Sociais, 26 (8): 123-148.

(1999), "Modelos de empresa, modelos de mundo: sobre algumas características culturais da nova ordem econômica e da resistência a ela". Revista Brasileira de Ciências Sociais, 14 (41): 121-140.

(2003a), "Fundos de pensão no Brasil do final do século XX: guerra cultural, modelos de capitalismo e os destinos das classes médias. Mana, 9 (2): 7-38.

. (2003b), "Atores e ações na construção da governança corporativa brasileira ". Revista Brasileira de Ciências Sociais, 18 (52): 139-161. 
. (2004a), "A evolução recente do espaço financeiro no Brasil e alguns reflexos na cena política". Dados - Revista de Ciências Sociais, 47: 5-47.

(2004b), "A sociologia das finanças e a nova geografia do poder no Brasil". Tempo Social, 16 (2): 151-176.

. (2005a), "O 'nó' dos fundos de pensão e os dilemas da sociedade brasileira". Novos Estudos Cebrap, 73: 19-31.

. (2005b), "Convergência das elites e inovações financeiras: a governança corporativa no Brasil". Revista Brasileira de Ciências Sociais, 20 (58): 67-90.

(2006), "Escândalos, marolas e mudanças: para uma sociologia da transformação simbólica”. Trabalho do Núcleo de Estudos em Sociologia Econômica e das Finanças. São Carlos, SP, UFScar.

GUEX, S. (2003), "La politique des caisses vides: État, finances publiques et mondialisation". Actes de la Recherche en Sciences Sociales, 146-147: 51-61.

GUILHOT, N. (2004), "Une vocation philanthropique: Georges Soros, les sciences sociales et la régulation du marché mondial". Actes de la Recherche en Sciences Sociales, 151-152: 36-48.

(2006), Financiers, philanthropes: sociologie de Wall Street. Paris, Raisons d'Agir (col. Cours et Travaux).

HACKING, I. (1983), Representing and intervening: introductory topics in the philosophy of natural science. Cambridge/Nova York, Cambridge University Press.

HIRSCHMAN, A. O. (1992), "Rival views of market society", in A. O. Hirschman (ed.), Rival views of market society and other recent essays, Cambridge, Mass., Harvard University Press.

JARDIM, M. A. C. (2005), "Criação e gestão dos fundos de pensão: movimento sindical como ator relevante". Trabalho apresen- tado no XII Congresso Brasileiro de Sociologia, Belo Horizonte.

KNORR-CETINA, K. \& BRUEGGER, U. (2002), "Global microstructures: the virtual societies of financial markets". American Journal of Sociology, 107 (4): 905-950.

LABATON, S. (2002), "Bush tries to shrink S.E.C. Raise Intended for Corporate Cleanup". New York Times, 19/10.

LAKOFF, G. (1996), Moral politics: what conserva tives know that liberals don't. Chicago, The University of Chicago Press.

LEITE, J. (2005), "Banqueiro ganhou fama com Collor". Folha de S. Paulo, 14/4.

LÍRIO, S. (2005), "O orelhudo tá nessa: as conexões entre Daniel Dantas, Marcos Valério, integrantes do PT e o depoimento da secretária". Carta Capital, $29 / 6$.

LORDON, F. (2002), La politique du capital. Paris, Odile Jacob.

LOUREIRO, M. R. G. (1997), Os economistas no governo: gestão econômica e democra cia. Rio de Janeiro, Fundação Getulio Vargas Editora.

MACKENZIE, D. (2001), "Physics and finance: sterms and modern finance as a topic for science studies". Science Technology \& Human Values, 26: 115-144.

. (2006), An engine, not a camera: bow financial models shape markets. Cambridge, Mass., MIT Press.

MAIO, M. C. (1992), Nem Rotschild nem Trotsky: o pensamento anti-semita de Gustavo Barroso. Rio de Janeiro, Imago (série Diversos).

MARQUES, C. J. (2002), “A venda do caos”. Istoé Dinbeiro, $12 / 6$.

MARQUES, H. (2006), "Parlamentares cobram punição para Dantas". Jornal do Brasil, $31 / 3$. 
MARRUS, M. R. (1985), Les juifs de France à l'épo que de l'affaire Dreyfus. Bruxelles, Editions Complexe.

McGERR, M. E. (1986), The decline of popular politics: the American North, 1865-1928. Nova York, Oxford University Press.

(2005), A fierce discontent: the rise and fall of the progressive movement in America, 1870-1920. Nova York, Oxford University Press.

MENDES, V. (2006), "Cresce cobrança da BrT sobre Daniel Dantas: montante exigido do banqueiro a título de ressarcimento já supera R\$ 600 mi”. O Estado de São Paulo, 3/6.

MICHAEL, I. D. A. (2004), "Kroll tinha fortes ligações com a área policial, diz PF". Folba de São Paulo, 4/8.

MILLER, J. (1997), "What makes ted turner give? Others' examples". New York Times, 20/9.

MURPHY, P. (2002), "Esquerda e Bovespa fazem aliança estratégica: para presidente da Bolsa, 'muro de Berlim caiu' com a inédita visita de Lula ao pregão". O Estado de São Paulo, 1/9.

NEVEU, E. (1996), Sociologie des mouvements sociaux. Paris, La Découverte (col. Repères).

NIKONOFF, J. (1999), La comâedie des fonds de pension: une faillite intellectuelle. Paris, Arlâea.

OLMOS, M. (2003), "Montadoras esperam ajuda do governo Bush: atoladas em imenso passivo trabalhista, americanas não conseguem vencer concorrência japonesa”. Valor Econômico, 22/9.

PAVINI, D. C. E. A. (2005), "Polêmicas marcaram a elaboração da carteira”. Valor Econômico, 7/4.

PEÑA, Bernardo de la. (2005), "Crise política: Valério não soube explicar a origem do dinheiro, que parlamentares da CPI consideraram suspeita. O Globo, 8/7.
PERROW, C. (1990), "Economic theories of organization", in S. Z. A. P. Dimaggio (ed.), Structures of capital: the social organi zation of the economy, Nova York, Cambridge University Press.

PINÇON, M. \& PINÇON-CHARLOT, M. (1998), Grandes fortunes: dynasties familiales et formes de richesse en France. Paris, Payot \& Rivages.

RACY, S. (2006), "Ex-diretor de banco diz que PT pressionou". O Estado de S. Paulo, 16/5.

RECONDO, F. (2006), "Dantas nega extorsão, mas confirma encontro entre Delúbio e exsócio". Folba de São Paulo, 7/6.

RIEDER, J. (1990), "Rhetoric of reason, rhetoric of passion: sociolinguistic aspects of instrumental and expressive rhetorics". Rationality and Society, 2 (2): 190-213.

RIPARDO, S. (2002), "Projeto Bovespa-Lula reedita propostas do plano diretor de abril". Folha Online, 1/10.

ROMERO, C. (2005), "Disputa entre Dantas e fundos de pensão dividiu Gushiken e Dirceu e envolveu até Clinton: a briga que ameaça o governo Lula". Valor Econômico, 14/9.

SANGER, David E. \& OPPEL, Richard A. J. (2002), "Corporate conduct: the overview; senate approves a broad overhaul of business laws". The New York Times, 16/7.

SARTORE, M. D. S. (2006), A inserção da responsabilidade social do setor bancário no contexto da governança corporativa. São Carlos, SP, dissertação de mestrado, Universidade Federal de São Carlos.

SCHOR, R. (1992), L'antisémitisme en France pendant les années trente: prélude à Vichy. Bruxelles, Complexe.

SCHUMPETER, J. A. \& Swedberg, R. (1991), The economics and sociology of capitalism. Princeton, N.J., Princeton University Press.

SENADO. (2005a), "Notas da Comissão Parlamentar de Inquérito referentes à 
$21^{\mathrm{a}}$. Reunião Ordinária da CPI: compra de votos (mista) de 21/9/2005". Senado Federal, Brasília.

(2005b), "Depoimento de Daniel Dantas à Comissão Parlamentar Mista de Inquérito sobre a compra de votos". Brasília, 21/9 (arquivo da TV Senado).

SOUZA, L. \& ALENCAR, K. (2005), "Deputado do PFL 'clona' ação a favor do Opportunity". Folha de São Paulo, 23/8.

STROM, S. (2006), "Gates's charity races to spend buffett billions". New York Times, 13/8.

THE ECONOMIST. (2002), "The 685 billion reais question: will Brazil be forced to default if the opposition win october's presidential poll?". The Economist, 13/6. . (1994), "Ready to take on the world". The Economist, 15/1.

THOMPSON, P. (1997a), "The pyrrhic victory of gentlemanly capitalism: the financial elite of the city of London, 1945-1990". Journal of the Contemporary History, 32 (3): 283-304.

. (1997b), "The pyrrhic victory of gentlemanly capitalism: the financial elite of the city of London, 1945-1990". Journal of Contemporary History, 32 (4): 427440 , parte 2 .

TIEZZI, R. (2006), A Usina da injustiça. São Paulo, Geração Editorial.

TRAUMANN, D. F. E. T. (2002). "O xadrez de Arminio: o presidente do BC tenta aproximar o governo Bush e a oposição em busca de acordo preventivo com o FMI". Época, 18/7.

TROSTER, R. L. (2004), "Conspiração de bancos". Folha de São Paulo, 26/3.

VALOR ECONÔMICO. (2006), "Daniel Dantas diz ter sido prejudicado pelo governo e ameaçado por Casseb". Valor Econômico, $7 / 6$.

(2003), "Brasil estudará menor compulsório, cadastro positivo e autonomia do BC". Valor Econômico, 16/12.
VIEIRA, H. M. e. C. (2003), "Briga na telefonia Sérgio Rosa aponta os desacertos entre os sócios e o fundo de investimentos na Brasil Telecom: Previ e BNDES buscam adesões contra Opportunity". Valor Econômico, 1/10.

(2006), "Fiscal de gestores". Valor Econômico, 17/8.

VIRARD, P. A. E. M.-P. (2006), "Vers une guerre des générations". Le Monde, 15/8. 
ENTRE A PLUTOCRACIA E A LEGITIMAÇÃO DA DOMINAÇÃO FINANCEIRA

Roberto Grün

Palavras-chave: Sociologia financeira; Escândalos financeiros; Plutocracia.

À primeira vista, o universo financeiro parece opaco para a análise sociológica. Uma maneira de adentrar esse importante espaço da realidade brasileira atual é por meio do registro da atuação de algumas de suas figuras públicas e dos embates internos e externos que essas aparições suscitam. Este artigo mostra algumas características desse "campo" de atuação, em especial as que o dinamizam internamente, e sua relação com a sociedade inclusiva.

\section{BETWEEN PLUTOCRACY AND THE LEGITIMATION OF FINAN- CIAL DOMINATION}

Roberto Grün

Keywords: Financial Sociology; Financial scandals; Plutocracy.

At a first sight the financial universe seems opaque for a sociological analysis. One of the ways of entering this important space in the current Brazilian reality is by registering the performance of some public figures and the internal and outside shocks that such appearances cause. This article shows some characteristics of this "field," especially those that internally dynamize it, as well as its relation with the inclusive society.
ENTRE PLOUTOCRATIE ET LEGITIMATION DE LA DOMINATION FINANCIÈRE

Roberto Grün

Mots-clés: Sociologie financière; Scandales financiers; Ploutocratie.

L'univers financier semble, à première vue, opaque à l'analyse sociologique. Une manière de pénétrer cet espace important de la réalité brésilienne actuelle est par le registre de la performance de certaines de ses personnalités publiques et des heurts internes et externes que ces apparitions suscitent. Cet article montre quelques caractéristiques de ce "domaine" de représentation, en particulier celles qui le dynamisent internement, et leurs rapports avec la société inclusive. 